\title{
Human Security, Peacebuilding, and the Responsibility to Protect in East Asia
}

\author{
Brendan Howe
}

\begin{abstract}
East Asia is a region deeply affected by colonial, ideological, and national wars. At the level of international governance, security organizations in the region have looked to minimize the worst manifestations of interstate conflict through emphasizing non-intervention; while domestic governance has emphasized national interest and strength in terms of security and economic growth. East Asian challenges to normative universalism can be defined in cultural, economic, and political terms. This article, however, considers not only the threats to human security in East Asia, but also the roles that East Asian actors play in protecting and promoting human security, noting that under certain conditions, East Asian perspectives may be able to secure, in terms of human security, better results than could be achieved through extra-regional intervention.
\end{abstract}

Keywords East Asia, human security, peacebuilding, responsibility to protect, intervention

\section{Introduction}

This article addresses the epistemological traditions and physical experiences which have helped shape a uniquely East Asian take on governance and policymaking, as well as assessing the contributions by the major regional actors to human security in theory and practice. This is followed by consideration of some of the obstacles to providing safe havens free from fear, want, and indignity for the most vulnerable in the region. The case studies selected are those with major ongoing human security issues, but which have received significant attention from Western and East Asian actors attempting to address these challenges.

East Asia (including the sub-regions of Northeast Asia and Southeast Asia) is a region deeply affected by conflict. Colonial, ideological, and national wars have left their scars and legacies, including disputed borders and divided loyalties. 
Perhaps not surprisingly, therefore, states in the region have looked to minimize the worst manifestations of interstate conflict through emphasizing nonintervention, while domestic governance has emphasized national interest and strength in terms of security and economic growth. The constitutive documents of regional organizations such as the Association of Southeast Asian Nations (ASEAN) and the Shanghai Cooperation Organisation (SCO) also reflect this state-centric focus. East Asia, therefore, has been dominated by the national security paradigm, the principles of absolute sovereignty, and non-interference in domestic affairs, with humanitarian assistance or intervention regarded as, potentially, illegitimate interference (Acharya 2002, 377).

Meanwhile, the very idea of human security can be regarded as a Western legacy, stemming from liberalism (Rothschild 1995, 60-61); and thereby challenged by claims of cultural specificity (Acharya 2001, 1). Although perhaps no other region on earth is as culturally and socio-economically diverse, opposition to Western liberal or universal cosmopolitan values emanating from Asia has tended to be identified collectively as the challenge of "Asian values" (Khong 1997). While the Asian values debate per se has run out of steam and the paradigm defined as such has been discredited by association with authoritarian governments in East Asia, there nevertheless remain clear differences in interpretation of international norms relating to human security, peacebuilding and the responsibility to protect (R2P).

The Asian challenge to normative universalism can be seen in cultural, economic, and political terms. Culturally, it asserts that the Western liberal or universalist approach ignores the specific cultural traditions and historical circumstances of Asian societies, whose interpretations of human rights are different from those in the West. Economically, it maintains that the priority of developing Asian societies has to be the eradication of poverty. Politically it calls into question the motives of the West accusing them of using human rights merely as an instrument for advancing Western economic or security interests"power politics in disguise" and a shallow pretense for the use of force against regimes which stand up to Western neo-imperialism (Thompson 2004, 1085).

Essentially the "West" holds a narrow view of human security, but an interventionary interpretation of the R2P, with the two being closely linked; whereas in East Asia the linkage between the two is rejected, and a broad conceptualization of human security along with a non-interventionary understanding of the R2P dominates. The following sections explore the extent to which there remain East Asian perspectives on human security, peacebuilding, and the R2P, whether these perspectives have enough in common to be considered an "Asian Way," and how they diverge from Western perspectives. Furthermore, the article considers, through analysis of regional cases of insecurity, the extent to which this divergence may be beneficial, opening policy space for East Asian actors to protect and promote human security in the region, 
either solely from an Asian perspective or in concert with the West.

\section{East Asian Perspectives on Human Security, Peacebuilding, and the R2P}

Bellamy and Drummond $(2011,196)$ assert that, since the turn of the millennium, many states in the East Asian region are moving away from traditional notions towards accepting a localized variant of "sovereignty as responsibility" that allows for criticism of domestic polices and limited diplomatic pressure in the event of humanitarian crises. There has been convergence on the primacy of human security considerations, and an acceptance of the principles of the R2P (Bellamy and Davies 2009, 561).

Despite a degree of convergence on R2P however, it is clear that East Asian states maintain a distinct understanding of what it implies and its relationship with human security. For instance, the Permanent Representative of South Korea to the UN stressed "the primary responsibility lies in the individual Government while the international community bears the secondary responsibility," that R2P is "distinctly different from humanitarian intervention since it is based on collective actions, in accordance with the UN Charter," and that "not all humanitarian tragedies or human rights violations can or should activate R2P" (Park 2009). In Japanese thinking, there is a significant difference between human security and R2P perspectives: "while R2P recognizes the necessity for enforcement in certain circumstances, human security rules it out in every occasion," thus the Japanese focus is one of prevention reducing the need for intervention (Bellamy and Davies 2009, 552). We need first, therefore, to understand the problems human security champions in the East Asian region have with the universalist perspective championed by Western actors.

\section{East Asian Critiques of Western Liberal Universalism}

There are three main criticisms of liberal universalist approach to human security and peacebuilding. First, that Western "liberal" approaches in practice do not match the universal principles to which they aspire and from which they claim legitimacy, with selectivity in selection of peacebuilding activities often dictated by the interests of the intervening state(s) and often illiberal practices carried out during the intervention (Selby 2013, 57). Second, that these approaches are hegemonic and hierarchical in terms of both actors and issues, prioritizing what Western liberal societies or Western-dominated institutions think is good for the "benefitted" (democracy, the organization of elections, human rights and the rule of law, neo-liberal development, and the creation of an open market economy) rather than considering local circumstances and interests (Autesserre 2011, 4; Richmond 2006, 291-314). Third, that Western human security promotion and 
liberal peacebuilding are essentially top-down in nature, rather than bottomup, and that this is unsuited to transforming conflictual relationships or building resilient post-crisis societies (Lederach 1998, 1999).

Earl Conteh-Morgan $(2005,69)$ further notes that human security at the personal, institutional, and structural-cultural levels can be more effectively realized in the process of peacebuilding if "culture and identity and an interpretive bottom-up approach to peacebuilding are taken into account when addressing the problems of marginalized individuals, groups, and communities;" and both material as well as socio-cultural contexts are considered critical factors. This, then, represents a key departure from the universalist aspirations of the Western liberal peacebuilding paradigm. Likewise, for John Paul Lederach (1998, 20, 94), peace is a dynamic social construct, which requires continuous maintenance, and as the greatest prospects for sustaining peace in the long-term are rooted in the local people and their cultures, they should be seen as resources, not recipients.

Although the concept of human security has, over the last three decades, become widely recognized at the theoretical level, the twin concepts of freedom from fear and freedom from want that remain central to human security discourse are at the basis of a schism within the practitioner community. Proponents of a "narrow" concept focus on violent threats to individuals. Proponents of the "broad" concept argue that the threat agenda should be expanded to include hunger, disease, and natural disasters because these kill far more people than war, genocide, and terrorism combined. Western approaches to the promotion of human security in East Asia have tended towards top-down liberal interventions, political freedoms and democracy, the rule of law, and narrow freedom from physical threats. Asian approaches have tended towards constructive engagement, broad and development-based human security, and non-interventionary consensual partnerships with governments to address challenges. These competing perspectives can perhaps best be illustrated by brief consideration of the related policies of the greatest champions of the paradigm in each region-Canada in the West, and Japan in Asia.

Canada was the first state to embrace human security as a guiding point for development and peace-building activities, and it has prioritized the promotion of human security in the post-Cold war period as part of its active international involvement (Bernard 2006, 233-34). Canada's foreign policy identity selfimaging has long been as a "helpful fixer," "honest broker," and "international dogooder" (Bosold 2007, 175-200). As a major contributor to United Nations (UN) Peacekeeping Operations in the former Yugoslavia, Rwanda, Somalia, and other conflict areas, the Canadian government began to advocate the need to protect civilians in armed conflict situations within state borders and stressed the need to rethink the notion of humanitarian intervention (Axworthy 1997, 183-96).

Two international governance policy initiatives reflect Canada's rethinking on human security: the Ottawa Convention to Ban Anti-Personal Landmines 
and the creation of the International Criminal Court (ICC). Foreign Minister Lloyd Axworthy, one of the foremost champions of the paradigm, also called for addressing human security issues through humanitarian-inspired intervention by saying that human security "is going to have to be reconciled with the principle of non-intervention in the internal affairs of states" and the concept of national sovereignty "cannot be absolute" (Hubert and Bonser 2001, 111-21). This stance led Canada to provide global leadership in the International Commission on Intervention and State Sovereignty (ICISS), the final report of which entitled "The Responsibility to Protect" dealt with questions of when to intervene, under whose authority, and how (ICISS 2001).

Meanwhile, constrained by its pacifist constitution and lingering animosity in the region over Japan's historic role, planners have looked to non-traditional security policies to further Japanese interests (Howe 2010). These conditions have provided added impetus for successive Japanese governments to develop nonmilitary concepts of security and to practice them in order to play a leadership role in the global politico-strategic sphere. In particular, the emergence of the human security concept within security discourse allowed the country to combine its traditional regional aid operations with an initiative with global reach. Given internal and external structural constraints on the use of force, Japan has consistently tried to pursue its foreign policy through economic means, such as official development assistance (ODA) and foreign direct investment and loans, rather than by military means. Indeed, these anti-military, pro-economic norms have become characteristic of Japanese foreign and security policy (Berger 1993, 119-50). The recognition of the concept of human security in Japan is related to both the Asian financial crisis and the desire to play a bigger (albeit non-interventionary) role in international society under the concept of proactive pacifism (Soeya 2005; Acharya and Acharya 2000, 12).

By focusing on the economic and development aspects of human security and supporting wholeheartedly the broad approach outlined by the United Nations Development Programme (UNDP), Japan has been accused of contributing to a schism within the paradigm and community, placing the Japanese approach at odds with that of Western countries such as Canada and the Nordic states (Edström 2008, 109-10). While human security was introduced to the mainstream of Japanese foreign policy by Prime Minister Keizo Obuchi in 1998, a similar concept was first outlined as a key foreign policy perspective and main objective of Japanese ODA disbursement in 1995 (Fukushima 2003, 132). According to a speech by Prime Minister Tomiichi Murayama at the UN World Summit for Social Development held in Copenhagen in 1995, Japan was trying to create a "human-centered society" and emphasized "human-centered social development" as a focus of Japanese ODA (Murayama 1995), thereby further embedding the notion of a strategic link between development, human security, and Japanese foreign and state security policy. 
The recognition of the concept of human security in Japan is related to both the Asian financial crisis and the desire to play a bigger role in international society under the concept of proactive pacifism (Soeya 2005; Acharya and Acharya 2000, 12). The crisis had a devastating impact on Asia's economy; increasing poverty and political instability and underscoring the crucial need for social safety nets for the poor and for a new understanding of security, focusing on Asian peoples rather than states (Acharya and Acharya, 2000). In the context of the crisis, Prime Minister Keizo Obuchi noted in his opening remarks at the "Intellectual Dialogue on Building Asia's Tomorrow" on December 2, 1998, saying "I believe that we must deal with these difficulties with due consideration for the socially vulnerable segments of population, in the light of 'Human Security', and that we must seek new strategies for economic development which attach importance to human security with a view to enhancing the long term development of our region" (Obuchi 1998a).

Obuchi committed to help Asian countries overcome crises and assist socially vulnerable people. He emphasized his perception of human security as being people-rather than state-centric, and that his understanding of human security was analogous to that of the UNDP. At the ASEAN+3 Summit in Hanoi on December 16, 1998, he advanced a vision of human security as "a comprehensive view of all threats to human survival, life, and dignity" (Obuchi 1998b). Together, these speeches laid the foundation for the rise to prominence of human security as the main pillar of Japan's foreign policy agenda. With the fusion of human security and ODA, Japanese aid policy has been transformed into a vehicle for transporting the human security idea (Konrad 2006, 22).

\section{An Asian Way?}

While Asia as a whole, and even the East Asian region, is too diverse to be considered monolithic in perspectives, nevertheless there are sufficient similarities between the human security promotion policies of regional actors to consider whether there is an East Asian way of doing things. These similarities go beyond the simple rejection of Western liberal universalism.

As mentioned above, Japan can be considered the human security trailblazer of the region. Japan has been at the forefront of regional ODA, has given considerable impetus to the comprehensive and human security agendas, and has served as a major contributor to international aid and relief organizations. Japanese aid and human security initiatives may well be motivated by national interest and far from altruistic. Nevertheless, a happy coincidence exists whereby Japanese aid has had a significant positive impact on human security and development in the region while simultaneously fulfilling Japanese strategic agendas. This can be seen in the analysis of the policy impact of East Asian actors in cases of regional insecurity outlined below.

Knowing the apprehension of developing countries towards the interven- 
tionary turn taken by other approaches, it is perhaps understandable that the Japanese government has focused on the developmental and economic aspect of human security. Japan's ability to work in politically problematic and/or (post-) conflict territories (as developed below) has been facilitated by its approach to human security and development, with its discursive emphasis on human security welcomed as a "particularly suitable replacement for Western liberal discourses on human rights, which are deeply unpopular in Asia and Africa" (Hynek 2012, 70). This is still not to suggest, however, that Japanese human security promotion is somehow apolitical or entirely altruistic. Rather, policymakers have identified a niche area where Japan can punch up to its weight in the international arena, if not above it, the pursuance of which will promote national interest at the same time as improving the image of Japan as a benevolent international actor. At the same time, collateral benefit accrues to the human security of the most vulnerable sections of Asian societies, and the concept is elevated on the global stage through Japanese support. As pointed out by Edström $(2011,25)$, "it seems that countries pursuing policies on human security have devised them to fit policies where they have seen themselves having a comparative advantage."

The reasons for Japan's leadership in human security promotion are in fact three-fold: to advance niche diplomatic interests by using ODA effectively as a diplomatic tool; to benefit vulnerable sections of the regional community; and to secure bureaucratic interests by gaining public support for human security promotion activities (Howe 2013, 202). Japan has provided inspiration for the human-centered policy initiatives of other regional actors (including for strategic competitors), as well as supporting directly human security initiatives in the East Asian region.

Indeed, these elements form the nucleus of an East Asian regional way of promoting human security, which despite significant differences, can be identified as commonalities among the other major regional actors. These include significant geostrategic constraints upon the exertion of traditional power and influence; the need, therefore, to explore areas of "niche diplomacy" in terms of both policy orientation and geographic regional concentration where actors can get more bang for their buck (or Yen or Won); significant linkage with ODA and a broad interpretation of human security/freedom from want; and an emphasis on consent and rejection of intervention, thereby securing support from domestic constituencies in both the human security promoting agent, and the regional partner country.

South Korea's status in foreign affairs is broadly recognized as being that of a middle power, both of its own accord as well as how it is perceived by the world, and in particular by its regional neighbors (Kim et al. 2018, 96; Howe 2017, 243-48). As such, the country is in even more need of developing an impactful niche for its diplomacy than is Japan. In the security field, due to geopolitical constraints, the Republic of Korea (ROK) is unable to perform the neutral or 
brokering role of traditional middle powers (Kalinowski and Cho 2012, 244). Thus, Seoul's major policy forays and initiatives in the security realm, like those of Tokyo, have tended to revolve around the intersection of security and development, and how this intersection contributes to peacebuilding (Kim et al. 2018, 102).

ROK human security promotion is driven in part by geostrategic constraints, in part by a "paying back syndrome" (Hong 2009, 24), in return for assistance received from the international community during and after the Korean War, and in part by competition with Japan (while simultaneously drawing inspiration from Tokyo's initiatives). The latter may be why the South Korean government seldom explicitly uses the term. Elements of human security have, nonetheless, suffused Korea's foreign policy. The first official occurrence of the term human security in Korean government documentation was in 2008 when it was used by the Korean Ministry of Foreign Affairs (MOFA). The term was used in broader discussions on foreign policy without an explicit focus on ODA. MOFA and the Korean International Cooperation Agency (KOICA), which is the agency tasked primarily with the distribution and management of Korean ODA, are the only two government institutions that have used the term "human security" in their official documents.

In the security field, MOFA has discussed the concept of human security as involving "Individual security and safety, protection of human rights, and protection of individual's basic necessities" thereby displaying a fairly comprehensive understanding of the term (Kim et al. 2018, 104). MOFA has further stated that "there is a need to cooperate at the regional and global levels to deal with traditional as well as non-traditional security threats" (ibid.). This is in line with the freedom from fear component of human security. Yet former Foreign Minister Yun Byung-se used human security at an international conference in 2013, on the theme "New Strategic Thinking: Planning for Korean Foreign Policy." This was the first time a Minster of Foreign Affairs used the term. He stated that the global policies of the Park Administration "reflect the belief that peace and prosperity of South Korea and the world are indivisible, and that there has been a global paradigm shift which emphasizes the importance of human security" (ibid.). This reflected a turn towards a broader interpretation of human security even within the security discourse. Within the aid community of Korea, as might be expected, human security conceptualizations are much more closely aligned with freedom from want.

Although the South Korean government rarely uses the term "human security" in its official documents, it has embraced the concept and its implications for ethical foreign policy fully. For example, MOFA affirms the goals for ODA as economic development and poverty reduction of developing countries (ibid.), and commitments based on humanitarianism and sustainable development (ibid.). South Korea has endorsed international humanitarian 
assistance for the protection of basic human rights of people and freedom from fear (ibid.). The first paragraph of Article 3 of the Framework Act on International Development Cooperation (2010) highlights reduction of poverty: human rights of women, children, and the handicapped, and gender equality; and sustainable development, humanitarianism, and peace (ODA Korea 2012a). MOFA included "strengthening of humanitarian assistance and peace building effort for the regions in conflict" in the six strategic goals of its ODA and aims gradually to increase ODA for human security and humanitarian assistance (Kim et al. 2018, 103). Thus, the ROK has also embraced broad "Asian" development and freedom from want perspectives in its human security agenda.

South Korea's humanitarian policies are based on four principles of humanity, neutrality, impartiality, and independence, with humanitarian assistance defined as an intervention to help people who are victims of a natural disaster or conflict to meet their basic needs and rights (KDR 2018). The South Korean government works closely with civil society organizations in particular before implementing humanitarian interventions in fragile states where armed conflicts have caused severe damage (ibid.). And civil society representatives urge the government to make sure that international humanitarian assistance is in accordance with international humanitarian laws and norms.

So, like Japan, South Korea's take on human security reflects significant geostrategic constraints upon the exertion of traditional power and influence, a niche diplomatic focus on humanitarian engagement within the region, significant linkage with ODA and a broad interpretation of human security/ freedom from want, and an emphasis on consent and civil society engagement. Furthermore, Japan and South Korea have contributed directly to the furtherance of human security in ASEAN member countries, but also to its promotion in the organization as a whole. This has helped facilitate a transition within the regional organization from the ASEAN way of non-interference to a people-centered ASEAN.

In July 1998, then Thai Foreign Minister Surin Pitsuwan proposed that ASEAN adopt a policy of flexible engagement, which involved discussions of fellow members' domestic policies. As noted by Pitsuwan himself (2008), although flexible engagement was not adopted as a form of enhanced interaction, ultimately the new "ASEAN political and security community" came to the fore, "which is much more intrusive, much more aggressive, much more alien to the ASEAN mental perception than my initial idea in 1998 about flexible engagement."

Bellamy and Drummond $(2011,196)$ assert that "many Southeast Asian states are moving away from the traditional notion of sovereignty... towards accepting a localized variant of sovereignty as responsibility" that allows for criticism of domestic policies and limited diplomatic pressure in the event of humanitarian crises. Likewise, Caballero-Anthony and Haywood $(2010,7)$ have 
noted a gradual shift in attitudes towards the principles of state sovereignty and non-interference, with "regional" security concerns at times outweighing concerns over "interference." They concluded that "the 'ASEAN way' is not an entirely static concept and what is considered interference in the domestic affairs of a country is an ever-widening notion" (ibid., 5).

This movement has culminated in the notion of a "people-centred ASEAN" first introduced in the declaration of Bali Concord II signed on October 2003. The Vientiane Action Programme (VAP) for 2004-2010, a six-year plan designed to initiate ASEAN community building comprising three pillars-Economic, Security, and Socio-Cultural Community-also emphasized ASEAN's peoplecentered approach (ASEAN 2004, 16). The term was further prioritized when ASEAN leaders, in their meeting in Kuala Lumpur in 2005, decided that the time had come for the organization to begin its process of transformation through an ASEAN Charter (Morada 2008). Based on the 2004 VAP, the leaders agreed to confer ASEAN a legal personality by drafting an ASEAN Charter that would serve as a constitution of ASEAN (ASEAN 2005). At the Twelfth ASEAN Summit in January 2007, in a speech entitled "One Caring and Sharing Community," President of the Philippines Gloria Macapagal-Arroyo stressed that "the ASEAN community we are building shall be a community of peoples caring for and sharing their human, natural and cultural resources and strengths for their common good and mutual benefit" (ASEAN 2007).

Although the ASEAN Charter, adopted at the Thirteenth ASEAN summit in November 2007, maintains the traditional emphasis on principles of sovereignty, territorial integrity, and non-interference, it adheres to numerous liberal and humanitarian notions, such as democratization, the protection of human rights and fundamental freedoms, and the empowerment of civil society (ASEAN 2008, 2). It also emphasizes promoting a people-oriented ASEAN as an approach to be implemented in ASEAN's key areas of cooperation: economic, political-security, and socio-cultural. In this regard, the Charter proposes "to promote a peopleoriented ASEAN in which all sectors of society are encouraged to participate in, and benefit from, the process of ASEAN integration and community building" (ibid., 5).

Although there are caveats concerning the extent of human security in the Charter related to the distinction between people-centered and people-orientated (Chandra 2009, 200; Oga 2014), nevertheless, in the ASEAN Community Vision 2025, adopted at the Twenty-Seventh ASEAN Summit in November 2015, a people-centered and people-oriented community was emphasized in order to maintain ASEAN as globally active and relevant (ASEAN 2015). The ASEAN Economic Community Blueprint 2025 also includes a number of human-centric reinforcing elements including a people-oriented and people-centered ASEAN (ibid., 5). Since the adoption of the ASEAN Charter and the invigoration of subsequent civil society movements, a gradual transformation of ASEAN's 
institutional mechanisms into a more people-oriented process has therefore taken place.

In fact, ASEAN currently embodies two theoretically conflicting, but potentially mutually supportive governance and policy-prioritization prescriptions: namely human security, as expressed in the concepts of people-centered or people-oriented and the ongoing importance of a state-centric, noninterventionary ASEAN way (Howe and Park 2017, 6). Indeed, ASEAN's response to a range of East Asian non-traditional security issues in recent years, such as the 1997 Asian financial crisis, the 2002-2004 SARS outbreak, the 2003-2004 avian flu outbreak, the 2004 Indian Ocean tsunami, the impact of cyclone Nargis in 2008, and most recently the Rohingya crisis, suggests that these new challenges have contributed to a realignment of the ASEAN Way (ibid., 12).

Thus, at least in theoretical and policy terms, while the concept of Asian values may have been discredited and there has been a degree of convergence in the direction of universal norms, there remains a disconnect between Western and Asian understandings of these norms and their policy implications, as well as an Asian way of conducting the promotion of human security, shared across regional actors. The next section addresses how these understandings and policy imperatives have played out in the face of some of the biggest regional challenges to human security.

\section{East Asian Human Security Promotion in Practice}

Despite dramatic progress in economic development, governance, and interstate security in Asia, major challenges to human security endure, some of which have even been exacerbated by the policy-making processes described above. Among the most serious challenges are the enduring legacies of conflict, poverty, environmental degradation, and "natural" disasters, which due to the contributions of human agency should perhaps be termed "natural-induced disasters." Each of these threatens human security individually, but also interacts with the others in a complex web of causality, with the human security of the most vulnerable being challenged along several different avenues. The following case studies not only highlight ongoing human security challenges in the region, but also the consequences of different paradigmatic and regional approaches.

\section{East Timor/Timor-Leste}

For Markus Benzing (2005, 297), East Timor stands out as "the most radical 'state-building' exercise the United Nations has engaged in to date, in the most literal sense of the word, as the United Nations acted as midwife for a new state." The UN played a vital role in East Timor's independence by organizing the 1999 popular consultation, which ended Indonesia's twenty-four-year occupation. 
The UN Transitional Administration in East Timor (UNTAET), ran from 1999 until 2002 with the aim of administering the territory, exercising legislative and executive authority during the transition period until independence, and supporting capacity-building for self-government. At the end of this period, with East Timor celebrating the recovery of its independence not only from Indonesia but also from the UN administration which followed, the UN felt able to laud its own achievements (UN Foundation 2002).

Optimistic assessments of the long-term future stability of East Timor upon independence proved, however, to be premature. UN peacekeeping troops had to return in 2006 in the guise of the Australian-led International Stabilisation Force (ISF) after fighting between sections of East Timorese police and military forces led to social and political instability. President José Ramos-Horta was critically injured in an armed attack on February 11, 2008, again leading to the Australian government sending reinforcements to keep order in response to a request from the government of East Timor (Platypus Magazine 2008, 22-23). UN operations in East Timor in fact, out of necessity, went far beyond peacekeeping. According to Hideaki Asahi (2012, 3-4), in the East Timorese context, "peace-building is tantamount to state-building," with reference to top-down, state-centric processes with a structural focus on putting in place the central- and national-level institutions of the state.

Despite a pre-existing indigenous system of community governance and justice, intervening forces perceived that East Timor lacked experience of selfrule, effective central government institutions, and laws, regulations, and other normative codes of control to bind or unite local communities and citizens. Thus, the first task of the international community was seen as being to foster the growth of indigenous "national" governance structures, which could serve as an overarching framework of state apparatus. Accordingly, therefore, Kamalesh Sharma, Special Representative of the Secretary General (SRSG) of the United Nations Mission of Support in East Timor (UNMISET), immediately identified the need to "Start from Scratch," overlooking the vital need to build on indigenous foundations (ibid., 4). This inability of the UN to identify and work with local mechanisms and customs undermined the legitimacy of the UN in the eyes of the local population.

The manner through which the UN peacekeeping operations (PKOs) engaged in state-building endeavors in East Timor can also be criticized for having fallen short of the UN standards themselves, namely "the respect [the UN peacekeeping operation] shows to local customs, institutions and laws, and the decency with which it treats the local people all have a direct effect upon perceptions of its legitimacy" (UNPKO 2008, 36-37). Although there were some initial successes, "four years after Timor-Leste gained independence, its police and army were fighting each other in the streets of Dili. The April-June 2006 crisis left both institutions in ruins and security again in the hands of international 
forces" (ICG 2008, i). International Crisis Group (ICG) traces the roots of the 2006 violence to decisions taken on the security sector in the years before and after independence in 2002 (ibid., 4).

Upon Indonesian withdrawal, the only major functioning security forces on the ground in East Timor were associated with the independence struggle, most prominently FALINTIL (the Forças Armadas da Libertação Nacional de Timor-Leste, or the Armed Forces of National Liberation of East Timor), which stayed in cantonment at Aileu in the run-up to the popular consultation, and for another seventeen months afterwards, while the UN wondered what to do with it (Howe and Uesugi 2016, 93). The unwillingness or inability of the UN to train the former guerrillas and integrate them into the new security sector was reflected by the fact that FALINTIL was not mentioned in UNSC Resolution 1272, but was rather "perceived as a problematic residue of the twenty-four year struggle for independence; a view which neglected the popular support and legitimacy FALINTIL enjoyed, at least in the eastern provinces" (Kocak 2013, 9). The UN administration missed the opportunity to disband FALINTIL, and at the same time stored up resentment in their ranks while focusing on developing the police forces.

In order to overcome shortcomings in indigenous personnel, UN administrators recruited over 350 Eastern Timorese former officers of the Indonesian National Police who were given four weeks transitional training. According to Hood $(2006,64)$, the UN's recruitment of cadets for the PNTL "was marred by inadequate consultation with the East Timorese on the force's composition, excessive reliance on former employees of the Indonesian police forces in East Timor, and the use of unsatisfactory 'western' [i.e. Euro-American] procedures for determining candidates' suitability."

In a relatively short period of time since regaining independence, TimorLeste has developed a comparatively good record of democratic competition and has firmly established many of the conditions for a working representative democracy. In 2012, the year in which only the tenth anniversary of new-founded independence was celebrated, there were three sets of free and fair elections (two presidential and one parliamentary) without significant disruption, allowing the withdrawal of UN peacekeepers to proceed as scheduled that December (DellaGiacoma 2012). Yet this may have been despite as much as because of Western dominated liberal peacebuilding by the UN. Indeed, UN operations in East Timor were often at odds with their indigenous counterparts. The upshot of the UN state-building project has been stability but with power concentrated in the hands of the few.

In contrast to what is spent on security and state-building projects encouraged by the UN which saw 30 percent of the budget allocated to a stabilization fund, only 3.98 percent of the budget has been allocated to the agricultural sector where over 80 percent of the population is employed, with 
the same proportion devoted to the health sector while education received 6.64 percent (Doraisami 2009, 169-70). Readily available funds from resources have led to poor planning and management, and currently high levels of expenditure have done little to significantly improve infrastructure, are not in line with the economy's absorption capacity, and are unlikely to increase private sector activity or employment (ibid., 172).

Both national and international governance agencies have encountered severe difficulties in spreading the benefits of economic development much beyond the boundaries of the capital. Despite expending US\$ 32 million in 2010 on the Decentralized Development Package aimed at infrastructure development in rural communities, critics contended that overall spending was still too concentrated in Dili and failed to benefit the 90-plus percent of the population living in rural districts (Arnold 2011, 218-19). The Petroleum Fund has given the government of Timor-Leste considerable economic freedom of movement but spending on economic stimulus measures and improvements to infrastructure have produced woeful returns. ICG notes that "in recent years, over half the state budget has been devoted to construction projects, but actual execution has sometimes seemed an afterthought. Limited investment in the weak education and health sectors is not doing enough to ensure the welfare of future generations" (ICG 2013).

The nation-building process of Timor-Leste faces significant demographic challenges due to a population growth which is the fastest in Asia and among the fastest in the world. Timor-Leste also has a distorted demographic curve with an early peak and a long tailing-off due to a large younger generation while many of the older generation perished during the struggle against Indonesia. The average age is only 17.3 years (Asahi 2012,14). The youth have become heavily involved with so-called "martial arts groups," some of which have taken on the characteristics of violent armed gangs (Pawelz 2015, 121). These groups have exacerbated and inflamed each crisis since independence, and disrupted elections with internecine violence, attacks against the instruments of the state, and intimidation and victimization of civil society. Yet the stimulus for Timorese youths to join these groups and engage in the destabilizing activities listed above is primarily economic, related to a failure of those who govern to provide havens free from want for the most vulnerable sections of society. Timor-Leste has a "shockingly high" unemployment rate, particularly among the youth (Guterres 2008,368 ). Ten to fifteen thousand unemployed youths are added to these figures annually (Akara 2011).

Domestic violence continues to be an issue in independent Timor-Leste, is the most common form of gender-based violence reported to the police, and, according to a baseline study in two Timorese districts published in 2009, is a "normal" occurrence for many Timorese women and often viewed as a private or family matter (Timor Leste Government 2011, 50). In 2009 domestic violence 
was entered in the penal code, making it a punishable crime for the first time, and also a public crime, which means people other than the victim have the power to report incidents of domestic violence to the police. "The recognition of domestic violence as a crime made it possible for the National Parliament to pass a longawaited Law Against Domestic Violence in May 2010" (ibid.). Since the passing of the law, however, continued obstacles such as "lack of rule of law, a feeble judicial system, economic dependence, and a culture of silence" mean that it remains the country's number one crime, accounting for around 50 percent of all crimes, and with nearly one-third of all women having experienced some form of violence or assault since the age of fifteen rising to one in two in the capital, Dili (Hodal 2012). Rita Reddy (2011), Senior Gender Advisor to UN Mission in Timor-Leste (UNMIT), noted that not only has conflict delayed women's advancement in Timor-Leste-and that the androcentric, patriarchal, overwhelmingly Catholic and conservative traditional society continues to place obstacles in front of them-but also that poverty, unemployment, gangs, and martial arts clubs are further endangering women.

In short, despite the nominal positive outlook, the credibility of the UNMIT as a security provider and interim law enforcer in East Timor was compromised. The 2006 upheavals suggested that rather than the success claimed by many commentators, initial state-building operations carried out under first UNTAET and then UNMISET were a failure (although the 2007 elections were mostly peaceful, they were extremely divisive). Despite the peaceful 2012 elections, and the withdrawal of the overwhelming majority of external mission personnel, the underlying foundations for long-term peace, stability, and development, have yet to have been fully laid. Toward the end of its term, faced with growing frustration of the Timorese leadership and their sense of national pride against the usurpation of sovereignty and imposition of governance structures, the legitimacy of the UNMIT eroded in the eyes of host population, further undermining its efficacy (Howe and Uesugi 2016, 11). The government of East Timor did not perceive the ongoing hosting of UN missions to be to its advantage, and thus did not extend its consent to continuing intrusion of its sovereignty by UNMIT. The lack of a development, freedom from want, and distributive justice focus has stored up human security challenges for the future. Thus, in general, a universalist approach which failed to take into account the roles and perspectives of domestic constituencies proved to be somewhat limited in promoting human security in the long-term.

Furthermore, Australia, the major external state actor in East Timor, although a regional power, has consistently demonstrated a Western perspective in dealing with regional challenges. Australia has been regarded as a "traditional middle power" at both the global and regional level, basing its foreign policy behavior on multilateralism and soft power while still reflecting the Concert of Europe Model in which smaller powers construct their identity relative to the 
great powers in the West. At the global level, Australia has avidly supported multilateral institutionalism, chairing the UN Security Council (UNSC) through 2013-14 and hosting the G20 in 2014. At the regional level, "engagement with Asia" has become a central theme in Australian public policy and in public debate about Australia's place in the world (Capling 2008, 601). Australian-led projects in the region have focused on food consumer protection, education, and population, with an emphasis on trade and investment promotion, market access, generalized system of preferences privileges, and aviation issues. Moreover, the ASEANAustralia Business Council for the private sector was established to complement the governmental-level cooperation initiatives (ASEAN Secretariat 1988).

Wilkins (2014) argues that the key purpose of this multilateralism and coalition-building as features of middle-power diplomacy is to forge and reinforce a liberal global and regional order conducive to Australia's security and prosperity. Prime Minister Rudd (2011) declared that "we seek to build and strengthen the global and regional rules-based order." Adler and Barnett $(1998,425)$ note that "Australia's attempt to convince its neighbors of the virtues of open regionalism, multilateralism, and market-led integration may also be considered as a case of attempted (though not quite successful) redefinition of the parameters of politics that are designed to make Asia safe for Australia." Successive governments have sought to mediate tensions between the powers. The "Australia in the Asian Century White Paper" (Australian Government 2012) declares that Australia "will promote cooperative arrangements among major powers in the region as the economic and strategic landscape shifts." In the words of Prime Minister Rudd (2011), "Australia sees itself as a middle power with global and regional interests."

Australia's role in Timor-Leste, therefore, has reflected self-imaging as a supporter of universal institutions, a Western freedom from fear perspective on human security and peacebuilding, and a trade and investment rather than development focus on freedom from want. Indeed, Canberra has repeatedly sought to maximize its own economic benefit at the expense of Timor-Leste, including siphoning off billions of dollars in revenue from the exploitation of contested oil and gas fields. Australia even illegally spied and bugged the Timorese delegation during negotiations on the maritime demarcation of the Timor Gap (continental shelf principle of mid-way line). Beeson (2019) has highlighted the irony, or perhaps hypocrisy, of Australia's position as one of the most outspoken and prominent supporters of the "rules-based international order" while flouting the rules when doing so is judged to be in the national interest, with the "most diplomatically embarrassing example of this...seen in Australia's treatment of its impoverished neighbor Timor-Leste."

On the other hand, although this case study demonstrates the shortcomings of Western and universalist perspectives on human security and peacebuilding, it also reflects the limitations of the Asian way. The East Timor humanitarian interventions did represent an early case of involvement of East Asian actors 
in PKOs; a human security-related policy arena within which there has been significant growth of regional interest and activity (Howe and Kondoch 2014). For the first time in history Japan sent its military personnel, albeit engineering units, to a UN peace operation. Other Asian and non-Western actors such as South Korea, Bangladesh, Fiji, Nepal, Pakistan, and Russia also contributed their troops to UNTAET. Even China sent a symbolic contribution of peace personnel. Japan, South Korea, and China have continued to be major "no strings attached" donors to Timor-Leste since independence and the ending of the UN missions.

Yet ASEAN's performance with regard to human security promotion in this case study has been mixed at best. During the Indonesian occupation of East Timor, ASEAN and its other members were reluctant to criticize one of their number for undermining the human security of vulnerable individuals and groups-the ASEAN Way was in full force. Even after Timorese independence, however, and Indonesian acquiescence in the matter, other member states, in particular Singapore, placed obstacles in the way of full Timorese membership and the human security and development benefits which would thereby be achieved. This obstructionism is due to the perceived financial and organizational burdens which would accrue to the organization and its existing members.

The ASEAN explanation is that with more than a thousand ASEAN meetings a year Timor-Leste simply lacks the capacity to participate fully. It would seem to this author, however, that rather than exclude a country from the benefits of full membership in the regional body, the answer to the dilemma lies in building capacity in Timor-Leste. This represents an avenue for human security promotion which could be profitably pursued by the Northeast Asian agencies (Japan and South Korea) which already contribute significantly to capacity- and institutionbuilding in ASEAN itself and in other challenging cases.

Thus, the case of East Timor demonstrates how lack of consent or ownership for recipient parties can be a major hindrance to furthering human security and capacity-building in challenging East Asian operating environments. The same conditions can also be found in the next case, governance failure in Myanmar, and the shortcomings of international responses.

\section{Myanmar}

Myanmar (also known as Burma) is a resource rich emerging economy in Southeast Asia but remains one of the poorest countries in the region. It has been and continues to be subject to conflicting external pressures from the East and West. Since independence from Britain in 1948, Myanmar has also experienced a complex set of conflicts between governments and people. Thus, both exogenous and endogenous governance challenges abound. For Smith $(2007,3)$ the country stands out as "a pre-eminent example of a post-colonial state subsumed in what development analysis describes as a 'conflict trap." Facing many challenges, including ethnic insurgencies and remnants of colonial experience, successive 
governments have adopted state-centric national security policies with an emphasis on national sovereignty, territorial integrity, and the national unity of diverse ethnic nationalities. Such policies have often impacted negatively on the human security of the most vulnerable and opened the governments of Myanmar to external criticism.

For the entirety of the period of military dominated governance, Myanmar could be considered a "severe" fragile state. During this time, the country faced the double challenge of underdevelopment and human insecurity and was also considered a difficult development partner due to its lack of political will to alleviate poverty (DAC 2001). As a result of such governance failure, Western actors not only withdrew assistance to the country, but also imposed significant sanctions.

By contrast, Japan has consistently featured as the largest aid donor to Myanmar and continued to provide assistance despite unacceptable behavior by the military government. Since the start of the military government in 1962, Myanmar has relied heavily on Japanese foreign aid (Oishi and Furuoka 2003, 898). Tokyo's ODA to Myanmar rapidly increased from the latter half of the 1970s when the military government relaxed its strict neutralist foreign policy and opened up to more ODA in order to overcome the country's economic and political crisis of the mid-1970s. The onset of the second military administration in 1988 undermined this favorable relationship, as Japan suspended its ODA on account of the junta's poor human rights record and delay in democratization. Tokyo did, however, recognize the military regime, and resumed economic assistance to the government of Myanmar the very next year. This was despite the fact, and perhaps because of it, that Myanmar's human security and development conditions worsened dramatically following the coup, and the military's atrocities against minority insurgencies were even more dreadful than they had been under the previous regime (Smith 1999). Tokyo's reasoning was that resumption of economic assistance was necessary to protect people and to ensure the survival and dignity of individuals as human beings.

It was, however, governance failure in the face of a natural disaster which truly drew international attention, but also exposed the extent of the schism between the Western and Asian paradigms of human security and R2P. Cyclone Nargis, which impacted Myanmar in early May 2008, was the deadliest storm to ever hit the country, and one of the most devastating recorded anywhere. Cyclone Nargis officially killed more than 140,000 people, although some commentators put the death toll at over 300,000 (UNEP 2009, 3). The government of Myanmar was accused of providing many affected people with almost no relief assistance while at the same time hampering external assistance (Özerdem 2010, 693).

The military leader of the country Senior General Than Shwe's major contribution in the immediate aftermath of Cyclone Nargis was to declare that the country was capable of handling the relief effort, but that it would allow limited 
international assistance so long as "no strings were attached" (Stover and Vinck 2008,729 ). Yet this was a gross over-estimation of the capacity of the government of Myanmar to address the humanitarian crisis, and an under-estimation of the limitations which would be placed upon international assistance. It was not until May 6 that the regime agreed to accept any foreign assistance. This agreement was still limited and did not lead to the huge and timely influx of international assistance needed. The government insisted on being able to control any distribution of aid which would ultimately be allowed in, following which it was "slow to issue visas to foreign specialists and to allow aid into Myanmar" (ibid). In fact, the government did not allow international experts and cargo ships with aid goods into its territory for several weeks (Kapucu 2011, 12). Even when this was somewhat relaxed, the government made it clear that only "friendly" countries would be allowed into Myanmar, denying naval vessels loaded with aid supplies from the United States, Britain, and France permission to land in Myanmar or to deliver any supplies by helicopter (Selth 2008, 388).

Western commentators and actors were overwhelmingly critical of the government of Myanmar, even to the extent of advocating intervention. Madeleine Albright (2008), the former U.S. Secretary of State thought the government to be criminally neglectful in its response. Gareth Evans (2008), president of the International Crisis Group from 2000 to 2009, one of the architects of the R2P, and a former Foreign Minister of Australia, reflected on whether it was "time for an aid invasion." Jean-Maurice Ripert, the French ambassador to the UN, used the language of R2P to attack the government of Myanmar (Özerdem 2010, 699), as did Bernard Kouchner, the French Minister for Foreign Affairs, who called on the UNSC to pass a resolution authorizing the delivery of aid even if this meant imposing it on the government of Myanmar in violation of state sovereignty (Barber 2009, 4). Specifically, Kouchner suggested that the R2P doctrine should be invoked as a response to the junta's refusal to allow international aid operations in the country, while it was failing to meet those needs through its own means.

This position found support among such Western human security pioneers as Lloyd Axworthy, the Minister of Foreign Affairs of Canada and driving force behind the ICISS, and Allan Rock, who was Canada's Ambassador to the UN (Özerdem 2010, 702). European Union (EU) foreign policy chief Javier Solana agreed the UN should use "all means necessary" to ensure that aid reached the most vulnerable, German sources indicated forcible delivery of assistance might be considered (Selth 2008, 390), and British Foreign Secretary David Miliband asserted the R2P could be applied to situations of natural disaster, further claiming that it is in fact a legal requirement of international governance (Barber 2009, 33). Australia's former Foreign Minister, Alexander Downer, agreed that "the concept of responsibility to protect needs to be extended to humanitarian assistance" while Prime Minister Kevin Rudd said the world needed to "bash the doors down in Burma" (ibid.). 
Pressure from the West over this issue, however, experienced considerable pushback from the non-Western sources. UNSC Permanent Members Russia and China, supported by some other Asian powers, argued that as the country was affected by a natural disaster, it would be better not to politicize the situation any further, but that rather it was the domestic affair of a sovereign state to decide how to assist its own people (Özerdem 2010, 701). There was something of an Asian consensus that such an "aid invasion" would amount to a gross violation of the sovereignty of Myanmar and went beyond the remit of the R2P. "Predictably, this was also the view of the [Myanmar government]" (Selth 2008, 390). NonWestern members of the ICISS also rejected the interpretations expounded by colleagues from the West. Ramesh Thakur argued that "there would be no better way to damage responsibility to protect beyond repair... than to have humanitarian assistance delivered into Myanmar backed by Western soldiers fighting in the jungles of Southeast Asia again" (Barber 2009, 10).

Meanwhile, as the West struck political postures, neighboring Asian countries, which were ultimately trusted by the government of Myanmar (after international pressures), were already delivering disaster response assistance. These included Chinese, Japanese, Russian, Indonesian and Singaporean disaster relief teams helping in search and rescue, mass care, medical relief, and other operations. Singaporean leadership facilitated the effective intervention of ASEAN through a tripartite ASEAN-UN-Myanmar government joint task force to coordinate, facilitate, and monitor international disaster relief assistance (Kapuchu 2011, 12). This case, therefore, threw a spotlight on the highly polarized and political nature of discussion related to both human security in general, and the R2P in particular.

Asian states were willing and able to provide international leadership in reaction to a humanitarian catastrophe in the region. John Holmes (2008), the UN's senior representative during the emergency, has noted that ASEAN's leadership was vital in building trust with the government and saving lives. Özerdem $(2010,704)$ further comments that the regional body spearheaded the aid effort. On May 15, 2008, fifty-one national representatives gathered at the ASEAN-UN International Pledging Conference on Cyclone Nargis where they agreed to form an ASEAN-led Tripartite Core Group (TCG) to assess impact and immediate humanitarian assistance as well as medium- to longer-term recovery needs. Özerdem (ibid., 704-05) claims that it was the prospect of this agreement that led to Than Shwe accepting Ban Ki-moon's proposal to open Myanmar's borders.

ASEAN's involvement and leadership made external interference more palatable (despite previous ASEAN criticism over Aung San Suu Kyi and the Saffron Revolution). In the case of governance failure in Myanmar, therefore, the combination of Western interventionary pressures, with Asian non-judgmental engagement, created the best conditions to facilitate governance transformation within a target state. Pressure from the West creates incentives not only for the 
target state to accept help, but also for Asian actors to offer it; while Asian offers of assistance are more readily accepted due to their anti-interventionary legacy.

The impact and aftermath of Nargis demonstrated the ongoing challenges posed by sovereignty issues and national security prioritization to the promotion of human security in Myanmar, and indeed the wider East Asian region. Hence Japan's focus on non-state-centric engagement, community-based peacebuilding, human security promotion, and disaster risk reduction (DRR) and resilience holds particular promise especially in crisis and disaster response scenarios. The Japanese approach has included providing massive financial assistance and currency swap arrangements in the aftermath of the Asian financial crisis to stabilize the regional economies and strengthen social and political stability. The country has engaged in peacebuilding in Cambodia, East Timor, Aceh, and Mindanao, and has been the largest provider of services in the conflict-affected regions of Myanmar (riven with ethnic, religious, and separatist confrontations between armed groups and the national military forces). Japan offered financial and medical assistance when East Asia was hit by the SARS epidemic; and deployed the largest contingent of Japanese troops since the end of World War II for humanitarian assistance to tsunami-stricken Aceh in early 2005 (Lam 2006, 143). Japan has, in fact, contributed the greatest amount of financial support to countries suffering from natural disasters (ibid.).

Japan has further contributed to capacity and resilience building in Myanmar. In 2012, the government of Myanmar expounded its vision of a centralized Emergency Operations Center (EOC) and welcomed international assistance to help it succeed in its vision. It became operational in 2015, just in time for the calamitous floods and landslides which stuck the country towards the end of the year. Despite twelve to fourteen regions and 1.6 million people being affected in five major events, and the EOC only recently having come on line, the coordinated response stood in stark contrast to Nargis. For sixty-seven days the EOC was able to carry out 24-hour situational monitoring, and Don Price, Incident Management Advisor and the EOC Chief Coordinator, was able to claim that this time no lives were lost as a result of bad management (Price 2016). Three ASEAN emergency response teams were quickly deployed, as well as one from UNDAC, with twelve UN agencies being involved with crucial roles carried out by the JICA(Japan International Cooperation Agency)-installed early warning system and very capable JICA project advisors on the ground (ibid.).

In total 316 travel authorizations were issued to any flood affected part of the country within four to twenty-four hours, as opposed to the two weeks which was previously the norm. The human security focus is clear from the list and order of SOP and guidelines displayed prominently in the EOC, to be referred to for all operational decision-making: RESPONSE-Save Life, Reduce Suffering, Protect Property, Protect Environment; RECOVERY_Livelihoods, Social Protection, Most Vulnerable Groups (Howe 2018, 126-27). For Price (2016), the level of 
local civil and military expertise and experience, combined with increased technological and organizational coordination, could now make Myanmar a benchmark for ASEAN.

Many of the sovereignty issues have significantly been resolved, with an increased receptiveness to international assistance manifesting even before the opening and eventual transformation of the regime. But national security and development continues to be prioritized at the expense of human-centered perspectives. Despite successive waves of people empowerment, first, in the immediate aftermath of Nargis, second, with the 2010 constitutional and governmental change, third, with the breakthrough in negotiations between the government, the military, and the NLD in 2011, and most recently with the election victory of the NLD in 2015, the most vulnerable sections of society remain endangered, under-empowered, and significantly without voice. This has become abundantly clear in the ongoing Rohingya crisis.

Again, with regard to international engagement with the government of Myanmar over the Rohingya, we can see the divergent Asian and Western paradigms at work. The United States has followed a traditional Western perspective on the crisis noting that the government of Myanmar needs to respect the rule of law, stop the violence, and end the displacement of civilians (USAID 2018). Canada has likewise reflected such a perspective, reaffirming a commitment "to advancing our core values in the pursuit of democracy, human rights, freedoms, and the rule of law," and imposing targeted sanctions against Major-General Maung Maung Soe (Canadian Government 2018). Meanwhile, China has followed the Asian non-interventionary, development-focused approach to safeguarding the human security of the most vulnerable, calling on the international community to "support the efforts of Myanmar in safeguarding the stability of its national development" (Osborne 2017).

Given, as detailed above, Japan is already heavily engaged in the promotion of human security in Myanmar, the Rohingya crisis would seem to present an important "noble opportunity" for South Korea to do something that is both normatively right and beneficial to others, while also in its national interest (Lee 2014, 2-3). The ROK has shown a willingness to pursue policies relevant to the promotion of human security in Myanmar which could come into play in any attempt by Seoul to address the Rohingya crisis. South Korea has consistently concentrated 30 percent of its total ODA to members of the ASEAN. The ASEAN-ROK Cooperation Fund, established in 1990 and having expended US\$ 81 million through the end of 2016, operates with an annual budget of US\$ 7 million serves to fund developmental projects dealing with technology transfer, human resource development, people to people exchanges, and exchanges of intellectuals between Korea and ASEAN (ASEAN-ROK). In 2010, in accordance with "the Strategic Plan for International Development Cooperation," the Korean government formulated Country Partnership Strategies for twenty-four priority 
partner countries in order to maximize synergy effects and to improve ODA effectiveness through strategic concentration (ODA Korea 2012b). The largest geographical concentration of priority countries was in Asia (eleven countries), with six ASEAN Member states including Myanmar (Howe and Park 2019, 131).

The Moon Jae-in administration in Seoul has shown considerable enthusiasm for human security promoting policies. According to the 100 Policy Tasks FiveYear Plan, the New Northern Policy, and the companion New Southern Policy, are a part of the Northeast Asia Plus Community of Responsibility project which aims to build a sustainable regional system of cooperation with ASEAN, the "middle power" grouping of MIKTA (Mexico, Indonesia, South Korea, Turkey, and Argentina), India, and Northeast Asian states. In particular, the "New Southern Policy" seeks to elevate the relationship between South Korea and ASEAN countries, as well as India, to the same level as the one between the ROK and its four strategic neighbors - the United States, Russia, China, and Japan (ibid., 118). Unfortunately, however, initiatives from successive administrations in Seoul to expand human security promoting engagement with Southeast Asia repeatedly come up against the challenges and distractions of realpolitik in Northeast Asia. As long as Seoul's policy elites remain focus on the traditional security considerations of the New Northern Policy, the human security aspects of the New Southern Policy will labor in its shadow.

Thus, although the combination of Western pressure and Asian engagement has significantly transformed governance and human security in Myanmar, the case study also demonstrates the need for the two approaches to be pursued in tandem. If this is not done, it seems that both paradigms are liable to fail in the objective of promoting human security in East Asia, as can be seen in the case study of North Korea.

\section{North Korea}

Since its inception in 1948, the regime at the helm of the Democratic People's Republic of Korea (DPRK) has neglected its duties to protect or guarantee minimal human security conditions for its citizens and has resisted becoming an international norm-abiding state. Human rights conditions have deteriorated significantly in the face of both endogenous and exogenous crises. Internal and external policy and governance failures have negatively impacted the daily lives of citizens, making them ever more insecure, as well as denying them the most fundamental human rights. Although largely the architect of its own internal insecurity dilemma, North Korea has been disadvantaged by developments in its international operating environment, fostering a belief in the need for, or justification of, policies that further undermine human security such as juche (self-reliance) and songun (military first).

Due to the externalization of internal insecurity by the Pyongyang regime, combined with flagrant human rights abuses within the country, North Korea has 
drawn significant international attention. Western and Asian actors have pursued a variety of strategies aimed at changing government policies in the DRPK in order to protect neighboring states, and to provide safe havens for the people of North Korea. The DPRK has promised repeatedly to abide by international rules, norms, and conventions, been punished for failing to live up to these promises, and then failed to amend its behavior in response to the punishments. The North Korean Human Rights Resolution has been adopted by the UN General Assembly every consecutive year since 2005 (Baek 2013, 123). The United States aggressively tackled the problem with the passage of the controversial North Korean Human Rights Act in 2004 (Howe 2006). But much of the focus of the international community, in particular in the West, has been on how to deal with the international threat posed by the DPRK rather than that which Pyongyang poses to its own people.

After North Korea's first nuclear test in October 2006, the UNSC immediately adopted Resolution 1718, which imposed a series of economic and commercial sanctions on the DPRK (Havel, Bondevik, and Wiesel 2008, 17). North Korea agreed to a complete shutdown of its nuclear reactor in February 2007, but then conducted a second nuclear test in May 2009, violating the agreement. The UNSC issued statements of concern and criticism, and on June 12, 2009 passed UNSC Resolution (UNSCR) 1874 condemning Pyongyang's actions, increasing existing sanctions, while adding some new provisions aimed at curtailing the regime's nuclear activities. In response to UNSCR 1874 Pyongyang asserted that "it has become an absolutely impossible option for North Korea to even think about giving up its nuclear weapons" (Fackler 2009). Indeed, a third nuclear test took place in February 2013. Despite little evidence of the success of such measures, the UNSC responded with Resolution 2094, further condemning North Korean actions and supposedly further tightening the sanctions regime.

Nolan $(2008,76)$ has, however, referred to the "non-impact" of UN sanctions imposed against the DPRK. Despite some disruption of economic activities in North Korea, they had little impact on the central decision-making core of the regime due to ongoing partial engagement with Beijing. Primarily, the impact of this sanctions regime, as with most others, has not been to effectively coerce the decision-making elites into behaving in a way that is acceptable to the international community, but rather to negatively impact the lower rungs of North Korean society.

Yet the unilateral development-led incentivization projects of successive South Korean governments also failed adequately to change North Korean policy-making or provide significantly better human security for the most vulnerable in North Korea. In 1998, South Korean President Kim Dae-jung initiated a positive engagement policy towards the DPRK called the "Sunshine Policy," which emphasized reconciliation and cooperation between the two sides (Kim 1999, 12, 64-65). In pursuit of these goals, the Republic of Korea (ROK) 
government provided the DPRK hundreds of thousands of tons of maize, flour, and chemical fertilizer with no pre-conditions (Chae 2001, 7). Learning from previous experiences, Seoul adopted practical operating principles such as "Easy tasks first, difficult tasks later," "Economy first, politics later," "Non-governmental organizations first, government later," and "Give first, take later" (Moon 2012, 26). Even with the souring of relations between the DPRK and ROK's patron, the United States, the Kim Dae-jung administration never stopped aiding the North.

The Roh Moo-hyun administration's "Peace and Prosperity Policy" largely inherited the main tenets of the Sunshine Policy. But the mounting tension between the United States and the DPRK over the nuclear issue and criticisms from conservative sectors of the South Korean public over sending aid without pre-conditions caused the new government to put greater emphasis on the principle of reciprocity than the previous administration had done (Koh 2005, 203-04). The Roh Moo-hyun Administration nevertheless tried to avoid damaging the improved inter-Korean relationship by pledging to supply 500,000 tons of food and 300,000 tons of fertilizer per annum. Following this, the ROK government granted 400,000 tons of rice on loan terms, sent 300,000 tons of fertilizer directly, and provided 100,000 tons of maize through the World Food Program (WFP) in 2003 and 2004 (Kim 2005, 16). In 2003, the ROK government also managed to persuade the United States to reach out to North Korea through a multilateral initiative to resolve the nuclear crisis: the "Six-Party Talks."

Responding to an appeal from the North Koreans to provide fertilizer in 2005, the South Korean government asked them to hold the inter-Korean viceministerial meetings in return, ultimately leading to the vice-ministerial meeting in May 2005. The ROK sent 350,000 tons of fertilizer and provided 500,000 tons of rice on loan terms in exchange in 2005 (MOU 2005, 174). Progress was, however, set back almost immediately by the Banco Delta Asia scandal resulting in the United States freezing North Korean funds after accusing the DPRK of counterfeiting and laundering U.S. dollars. In July, North Korea conducted ballistic missile tests followed by another nuclear test in October 2006 (UrRehman 2010, 10). After the missile tests, the ROK government suspended a food loan and the delivery of 100,000 tons of rice which had been pledged to North Korean flood victims in 2006 (Moon 2011, 21, 155).

On February 14, 2007, the Six-Party Talks progressed towards an agreement to implement a first phase of the September 19 Joint Statement, which caused the South Korean government to resume aid to the North. In 2007, the ROK government provided 400,000 tons of rice in the form of a loan, as well as 300,000 tons of fertilizer and 44,000 tons of food aid through the WFP (Gyeonggi 2012, 340; Moon 2011, 18). As the inter-Korean relationship improved, the Second Inter-Korean Summit was held in October 2007 between Kim Jong-il and Rho Moo-hyun. In the October 4 South-North Joint Declaration, announced on the final day of the summit, North Korea and South Korea reaffirmed the spirit of the 
June 15 Declaration and showed their willingness to build peace on the Korean peninsula through international relations and their economic cooperation with one other (Korea Times 2007).

Ultimately, however, with growing exasperation in the South at the intransigence of Pyongyang and the discrediting of unconditional assistance, the Lee Myung-bak administration in Seoul reverted to a more coercive engagement with the North, linking assistance with verifiable progress on certain key issues. Park Geun-hye's administration also effectively abandoned the unilateral benevolence approach to dealing with the crisis of governance in the DPRK. Assistance ground to a virtual stop.

The WFP $(2019,4)$ estimates that 10.1 million people (40 percent of the population) remain food insecure and in urgent need of food assistance. "Since January 2019, rations of the Public Distribution System (PDS) have been reduced to 300 grams per person per day (g/pp/day), which compares to 380 grams during the same period in 2018" and they may decline further (ibid.). Pyongyang has acknowledged that the country is suffering its worst drought in thirty-seven years and has called on its citizens to "battle" against the crop damage caused by it (BBC 2019b). The latest report of the United Nations' Special Rapporteur on the situation of human rights in the DPRK identified that the regime has violated economic, social, and cultural rights, not to mention the civil and political rights of their citizens (UNHRC 2019). North Korea has been described as the world's biggest open prison camp, with, according to a report by the U.S. State Department, between 80,000 and 120,000 people in prison (BBC 2019a). The condition of many prisoners in detention camps in the DPRK remains a critical issue (OHCHR 2017; BBC 2018).

Engagement with the DPRK by other Asian actors has been patchy at best. From Japan's perspective, there have been attempts to promote simultaneously traditional and non-traditional security in Northeast Asia through economic engagement and development cooperation. This was the rationale behind the huge amount of Japanese ODA disbursements to the People's Republic of China (PRC) during the last two decades of the twentieth century and the first decade of the twenty-first century (Howe 2013, 193). It was also the rationale behind Japan's participation in the Six Party Talks and the Korean Peninsula Energy Development Organization (KEDO), an organization founded on March 15, 1995 to implement the 1994 U.S.-North Korea Agreed Framework freezing DPRK nuclear power plant development in return for the construction of two light water reactor nuclear power plants. Both of these entities, however, founded on the realpolitik and power hierarchies of Northeast Asia, according to which Japan, sometimes described as a "reactive state," was particularly vulnerable (Calder 1998; 2005).

For ASEAN, the major vehicle for engagement with North Korea has been the ASEAN Regional Forum (ARF). The Twenty-Sixth ASEAN Ministerial 
Meeting and Post Ministerial Conference, held in Singapore on July 23-25, 1993, agreed to establish the ARF, and the inaugural meeting was held in Bangkok on July 25, 1994. The objectives were outlined as being: 1) to foster constructive dialogue and consultation on political and security issues of common interest and concern; and 2) to make significant contributions to efforts towards confidencebuilding and preventive diplomacy in the Asia-Pacific region (ASEAN Regional Forum). Importantly, not only did this organization represent a rare multilateral security institution which bridged Northeast and Southeast Asia, but it also included the participation of the DPRK. ASEAN, the embodiment of the ASEAN Way and non-interventionary perspectives of human security promotion, was to be in the driving seat. Again, however, this approach foundered on the rocks of Northeast Asian realpolitik. The significantly larger and more powerful (at least in traditional terms) states of Northeast Asia have proven unwilling to delegate collective action problem solving to their partners in Southeast Asia. Moreover, ASEAN and its members have enough problems to deal with in Southeast Asia (Chong 2018).

It was only with the simultaneous rise to power in early 2017 of Moon Jaein in the ROK and Donald Trump in the United States, with their very different politics and agendas, that a combination and synchronization of Asian and Western approaches led to a reinvigoration of the peacebuilding process on the Korean Peninsula and also greater hope for the provision of havens safe from fear, want, and indignity in the North. President Moon has achieved startling progress in terms of de-escalating rhetoric and conflict in Northeast Asia, has built bridges with the North and with China, has initiated unprecedented rounds of summit diplomacy, and has successfully recommenced family re-unification visits for those divided by the Korean War and partition of the country. Yet this was probably only possible because in the form of U.S. President Donald Trump, North Korea was faced with an adversary who appeared willing to think and do the unthinkable in re-starting the Korean War by striking or even invading the DRPK. Such a combination of Asian versus Western engagement has, controversially, been likened to a "good cop, bad cop" routine (Martin 2007, 6188).

To a great extent, the recent impetus for engagement by the United States under Trump, and by the ROK under Moon, has come from a combination of national geopolitical interest and domestic political factors. These also help to explain why, despite ongoing emphasis on state-centric considerations of security and development in the region, East Asian actors are increasingly willing to support human-centered policy and governance initiatives at both the domestic and international level. 


\section{Conclusion}

It is clear that even given the near universal acceptance of international governance norms revolving around the concepts of human security and the responsibility to protect, including explicit endorsement at the UN, there remain significant discrepancies in how these norms are interpreted and operationalized. At the theoretical level, the fault lines are between narrow and broad interpretations of human security, the relationship between human security and the R2P, and the extent to which the R2P is permissive of humanitarian intervention. At the level of practical policy implementation, these divergent approaches have been embodied in Western and Asian initiatives, including those of the most active and representative countries and organizations in their respective regions.

Yet East Asian actors and commentators have certainly become more engaged with the discourse, and this analysis of human security and the R2P in East Asia shows that the region is no longer the preserve of Westphalian state-centricity and sovereignty it has often been depicted. At the theoretical level, there is something of an overlapping consensus on the need for a human-centered approach, and the participatory or emancipatory inclusion of vulnerable groups, while at the practical implementation level, Western and Asian perspectives can actually end up as complimentary and mutually supportive rather than antagonistic. In order to address the ongoing crises in the region, both sides have important roles to play and need to work together with agencies on the ground to address, first and foremost, human vulnerabilities.

\section{References}

Acharya, Amitav. 2001. "Human Security: East versus West." International Journal 56 (3): 442-60.

Acharya, Amitav. 2002. "Redefining the Dilemmas of Humanitarian Intervention." Australian Journal of International Affairs 56 (3): 373-81.

Acharya, A., and Arabinda Acharya. 2000. "Human Security in Asia Pacific: Puzzle, Panacea or Peril?" Canadian Consortium on Asia Pacific Security Bulletin 27.

Adler, Emanuel, and Michael Barnett. 1998. "Studying Security Communities in Theory, Comparison, and History.” In Security Communities, ed. Emanuel Alder and Michael Barnett. Cambridge: Cambridge University Press, 413-41.

Akara, M. 2011. Founder of Luta Hamatuk NGO. Interview with author, Dili, August 5.

Albright, Madeleine. 2008. “The End of Intervention.” New York Times, June 11. http:// www.nytimes.com/2008/06/11/opinion/11albright.html (accessed October 5, 2019).

Arnold, Matthew B. 2011. “Timor-Leste in 2010: The Window for a 'Normal" Future?" Asian Survey 51 (1): 215-20.

Asahi, Hideaki. 2012. "An Uneasy Future for East Timor." http://www2.jiia.or.jp/en/pdf/ 
research/20120628eAn_Uneasy_Future_of_East_Timor.pdf (accessed October 5, 2019).

ASEAN (Association of Southeast Asian Nations). 2004. "Vientiane Action Programme." http://www.aseansec.org/Publ-VAP.pdf (accessed October 5, 2019).

ASEAN (Association of Southeast Asian Nations). 2005. "Kuala Lumpur Declaration on the Establishment of the ASEAN Charter." December 12. http://www.asean.org/64. htm (accessed October 5, 2019).

ASEAN (Association of Southeast Asian Nations). 2007. "Chairperson's Statement of the 12th ASEAN Summit H.E. the President Gloria Macapagal-Arroyo. 'ONE CARING AND SHARING COMMUNITY.” https://asean.org/?static_post=chairperson-sstatement-of-the-12th-asean-summit-he-the-president-gloria-macapagal-arroyoone-caring-and-sharing-community (accessed October 5, 2019).

ASEAN (Association of Southeast Asian Nations). 2008. "ASEAN Charter." http://www. asean.org/storage/images/ASEAN_RTK_2014/ASEAN_Charter.pdf (accessed October 5, 2019).

ASEAN (Association of Southeast Asian Nations). 2015. "ASEAN 2025: Forging Ahead Together." http://www.asean.org/storage/2015/12/ASEAN-2025-Forging-AheadTogether-final.pdf (accessed October 5, 2019).

ASEAN (Association of Southeast Asian Nations) Secretariat. 1988. "Meeting of the ASEAN Directors-General and Official of the Australian Government." In ASEAN Document Series, 1967-1988, ed. ASEAN Secretariat. Jakarta: ASEAN Secretariat.

Australia, Government of. 2012. "Australia in the Asian Century White Paper." http://www. defence.gov.au/whitepaper/2013/docs/australia_in_the_asian_century_white_paper. pdf (accessed October 5, 2019).

Autesserre, Severine. 2011. "Constructing Peace: Collective Understandings of Peace, Peacemaking, Peacekeeping, and Peacebuilding." Critique Internationale 51: 153-67.

Axworthy, Lloyd. 1997. "Canada and Human Security: The Need for Leadership." International Journal 52 (2): 183-96.

Baek, B.S. 2013. "Understanding and Future Prospects of the UN COI on North Korean Human Rights Situation.” Seoul: Korea Institute for National Unification (KINU).

Barber, Rebecca. 2009. “The Responsibility to Protect the Survivors of Natural Disaster: Cyclone Nargis, a Case Study." Journal of Conflict and Security Law 14 (1): 3-34.

BBC. 2018. "North Korea Frees Three US Detainees Ahead of Trump Summit." May 9. https://www.bbc.com/news/world-us-canada-44056972 (accessed October 5, 2019).

BBC. 2019a. "North Korea's human rights: What's not being talked about" February 18. https://www.bbc.com/news/world-asia-44234505 (accessed October 5, 2019).

BBC. 2019b. "North Korea Suffers Worst Drought in Decades" May 16. https://www.bbc. com/news/world-asia-48290957?intlink_from_url=https://www.bbc.com/news/ topics/cywd23g0gz5t/north-korea\&link_location=live-reporting-story (accessed October 5, 2019).

Beeson, Mark. 2019. "Australia Waives the Rules with Timor-Leste." The Strategist, September 4. https://www.aspistrategist.org.au/australia-waives-the-rules-with-timorleste/?fbclid=IwAR1Ndb4KbFc9-8BsMmjqf90UtM7LhwG3BWwWKqzCiMHx5D8K 7tSyDa_XtEk (accessed October 5, 2019).

Bellamy, Alex J., and Sara E. Davies. 2009. “The Responsibility to Protect in the Asia-Pacific Region.” Security Dialogue 40 (6): 547-74. 
Bellamy, Alex J., and Catherine Drummond. 2011. “The Responsibility to Protect in Southeast Asia: Between Noninterference and Sovereignty as Responsibility." The Pacific Review 24 (2): 179-200.

Benzing, Markus. 2005. "Midwifing a New State: The United Nations in East Timor." In Max Planck Yearbook of United Nations Law, Vol. 9, ed. Armin von Bogdandy and Rüdiger Wolfrum. Heidelberg: Max Planck Institute for Comparative Public Law and International Law, 295-372.

Berger, Thomas U. 1993. "From Sword to Chrysanthemum: Japan's Culture of AntiMilitarism." International Security 17 (4): 119-50.

Bernard, Prosper Jr. 2006. "Canada and Human Security: From the Axworthy Doctrine to Middle Power Internationalism." American Review of Canadian Studies 36 (2): 233 61.

Bosold, David. 2007. "The Politics of Self-Righteousness: Canada's Foreign Policy and the Human Security Agenda." In Transcultural Perspectives on Canada, ed. Klaus-Dieter Ertler and P. Mickiewicz. Brno: Masaryk University Press, 175-200.

Caballero-Anthony, Mely, and Holly Haywood. 2010. "Defining ASEAN's Role in Peace Operations: Helping to Bring Peacebuilding 'Upstream?”' Civil Military Working Papers 3/2010. Canberra: Asia Pacific Civil-Military Centre of Excellence.

Calder, Kent E. 1988. "Japanese Foreign Economic Policy Formation: Explaining the Reactive State." World Politics 40 (4): 517-41.

Calder, Kent E. 2005. "Halfway to Hegemony: Japan's Tortured Trajectory." Harvard International Review 27 (3): 46-49.

Canada, Government of. 2018. "Canada and the Crisis in Myanmar's Rakhine State." http:// international.gc.ca/world-monde/issues_development-enjeux_developpement/ response_conflict-reponse_conflits/crisis-crises/myanmar.aspx?lang=eng (accessed October 6, 2019).

Capling, Ann. 2008. “Twenty Years of Australia’s Engagement with Asia." Pacific Review 21 (5): 601-22.

Chae, Kyung-suk. 2001. “The Future of the Sunshine Policy: Strategies for Survival," East Asian Review 14 (4): 3-17.

Chandra, Alexander C. 2009. "Civil Society in Search of an Alternative Regionalism in ASEAN." Journal of Law and Politics 75 (4): 194-216.

Chong, Ja Ian. 2018. “Is ASEAN Still 'In the Driver's Seat' or Asleep at the Wheel?" East Asia Forum, March 11. https://www.eastasiaforum.org/2018/03/11/is-asean-still-in-thedrivers-seat-or-asleep-at-the-wheel (accessed October 6, 2019).

Conteh-Morgan, Earl. 2005. "Peacebuilding and Human Security: A Constructivist Perspective." International Journal of Peace Studies 10 (1): 69-86.

DAC (Development Assistance Committee). 2001. Poor Performers: Basic Approaches for Supporting Development in Difficult Partnerships. Paris: OECD.

Della-Giacoma, J. 2012. "Has Timor-Leste Left Behind Its Violent Past?” International Crisis Group, July 9. http://www.crisisgroupblogs.org/resolvingconflict/2012/07/09/hastimor-leste-left-behind-its-violent-past/?utm_source=wu9july\&utm_medium= timorlesteblog\&utm_campaign=wuemai (accessed October 6, 2019).

Doraisami, Anita. 2009. "Fiscal Policy Challenges in Timor-Leste: Is the Resources Curse on the Horizon?" ASEAN Economic Bulletin 26 (2): 164-73.

Edström, Bert. 2008. Japan and the Challenge of Human Security: The Founding of a New 
Policy 1995-2003. Stockholm: Institute for Security and Development Policy.

Edström, Bert. 2011. Japan and Human Security: The Derailing of a Foreign Policy Vision. Stockholm: Institute for Security and Development Policy.

Evans, Gareth. 2008. “Time for an Aid Invasion?” The Age, May 19. http://www.theage. com.au/news/opinion/time-for-an-aid-invasion/2008/05/18/1211049061508.html (accessed October 6, 2019).

Fackler, Martin. 2009. "North Korea Vows to Produce Nuclear Weapons.” New York Times, June 13. http://www.nytimes.com/2009/06/14/world/asia/14korea.html (accessed October 6, 2019).

Fukushima, Akiko. 2003. "Human Security and Japanese Foreign Policy." Paper presented at UNESCO/Korea Conference on Human Security, Seoul, Korea, June 16-17. http:// unesdoc.unesco.org/images/0013/001365/136506e.pdf (accessed October 6, 2019).

Guterres, Jose Cornelio. 2008. "Timor-Leste: A Year of Democratic Elections." Southeast Asian Affairs (2008): 359-72.

Gyeonggi Province. 2012. The White Paper on Gyeonggi Province's Inter-Korean Exchanges \& Cooperation 2001-2011. Gyeonggi Province.

Havel, Vacláv, Kjell Bondevik, and Elie Wiesel. 2008. "Failure to Protect: The Ongoing Challenges of North Korea." DLA Piper LLP, The Committee for Human Rights in North Korea and the Oslo Center for Peace and Human Rights. http://files.dlapiper. com/files/upload/NK_Report_F2P_North\%20Korea_Sep19_08.pdf (accessed October 6, 2019).

Hodal, Kate. 2012. “Timor-Leste Strives to Overcome Culture of Domestic Violence." The Guardian, August 24. http://www.guardian.co.uk/global-development/2012/aug/24/ timor-leste-strives-overcome-domestic-violence (accessed October 6, 2019).

Holmes, John. 2008. “Disaster Lessons.” Washington Post, August 6. http://www. washingtonpost.com/wp-dyn/content/article/2008/08/05/AR2008080502924.html (accessed October 6, 2019).

Hong, Kyudok. 2009. "South Korean Approaches to Peacekeeping and Peacebuilding: Lessons Learned and Challenges Ahead." The Journal of East Asian Affairs 23 (1): 2346.

Hood, Ludovic. 2006. "Security Sector Reform in East Timor, 1999-2004." International Peacekeeping 13 (1): 60-77.

Howe, Brendan. 2006. "Strategic Implications of the 2004 US North Korean HR Act." Asian Perspective 30 (1): 191-219.

Howe, Brendan. 2010. "Between Normality \& Uniqueness: Unwrapping the Enigma of Japanese Security Policy Decision-Making." Modern Asian Studies 44 (6): 1313-36.

Howe, Brendan. 2013. The Protection and Promotion of Human Security in East Asia. Basingstoke: Palgrave Macmillan.

Howe, Brendan. 2017. "Korea's Role for Peace-Building and Development in Asia." Asian Journal of Peacebuilding 5 (2): 243-66.

Howe, Brendan. 2018. "Cyclone Nargis in Myanmar: The Perfect Storm?" In Human Security and Cross-Border Cooperation in East Asia, eds. C. Hernandez, E. M. Kim, Y. Mine, and R. Xiao. London: Palgrave, 111-32.

Howe, Brendan, and Boris Kondoch. 2014. "The Politics, Challenges, and Future of UN Peacekeeping Contributions from the Asia-Pacific." Journal of International Peacekeeping 18 (3-4): 123-31. 
Howe, Brendan, and Min Joung Park. 2017. “The Evolution of the 'ASEAN Way': Embracing Human Security Perspectives." Asia-Pacific Social Science Review 16 (3): $1-15$.

Howe, Brendan, and Min Joung Park. 2019. "South Korea’s (Incomplete) Middle Power Diplomacy towards ASEAN” International Journal of Asia-Pacific Studies 15 (2): 117 42.

Howe, Brendan, and Yuji Uesugi. 2016. "The Legality and Legitimacy of UN Peacekeeping Operations in East Timor." Waseda Global Forum 12: 81-108.

Hubert, Don, and Michael Bonser. 2001. "Humanitarian Military Intervention." In Human Security and the New Diplomacy, eds. Rob McRae, and Don Hubert. Montreal: McGill-Queen's University Press, 111-21.

Hynek, Nik. 2012. “The Domopolitics of Japanese Human Security.” Security Dialogue 43 (2): 119-37.

ICG (International Crisis Group). 2008. “Timor-Leste: Security Sector Reform.” Asia Report $\mathrm{N}^{\circ} 14317$, January 17. https://www.crisisgroup.org/asia/south-east-asia/timorleste/timor-leste-security-sector-reform (accessed October 6, 2019).

ICG (International Crisis Group). 2013. “Timor-Leste: Stability at What Cost?” https:// www.crisisgroup.org/asia/south-east-asia/timor-leste/timor-leste-stability-what-cost (accessed October 6, 2019).

ICISS (International Commission on Intervention and State Sovereignty). 2001. The Responsibility to Protect: The Report of the International Commission on Intervention and State Sovereignty. Ottawa: International Development Research Centre.

Kalinowski, Thomas, and Hyekyung Cho. 2012. "Korea’s Search for a Global Role between Hard Economic Interests and Soft Power." European Journal of Development Research 24: $242-60$.

Kapucu, Naim. 2011. "Collaborative Governance in International Disasters: Nargis Cyclone in Myanmar and Sichuan Earthquake in China Cases." International Journal of Emergency Management 8 (1): 1-25.

KDR (Korea Disaster Relief). 2018. "The Four Principles of Humanitarian Assistance." http://humanitarian.koica.go.kr/c1/sub2.jsp (accessed October 6, 2019).

Kim, Choong Nam. 2005. "The Roh Moo Hyun Government's Policy Toward North Korea." East-West Center Working Papers, No 11, August. https://www.eastwestcenter.org/ system/tdf/private/PSwp011.pdf?file=1\&type=node\&id=32083 (accessed October 6, 2019).

Kim, Dae-jung. 1999. Government of the People - Collected Speeches of President. Seoul: Office of the President, the Republic of Korea.

Kim, Eun Mee, Brendan Howe, Seon Young Bae, and Ji Hyun Shin. 2018. "South Korea's Middle Power Diplomacy in Development and Human Security." In Regional Cooperation for Peace and Development: Japan and South Korea in Southeast Asia, ed. Brendan Howe. London: Routledge.

Kocak, Deniz. 2013. "Security Sector Reconstruction in a Post-Conflict Country: Lessons from Timor-Leste.” SFB-Governance Working Paper Series, No. 61, October. https://www.sfb-governance.de/publikationen/sfb-700-working_papers/wp61/SFBGovernance-Working-Paper-61.pdf (accessed October 6, 2019).

Koh, Y.H. 2005. “Two Years of the Roh Moo-hyun Administration's North Korea Policy." Sejong Policy Studies 1 (2), 5-32. 
Konrad, Corinna. 2006. “The Japanese Approach: Tracks of Human Security Implementation.” Human Security Perspectives 1 (3): 22-38.

Khong, C. O. 1997. "Asian Values: The Debate Revisited." Talk given at the First Shizuoka Asia-Pacific Forum: The Future of the Asia-Pacific Region at Hamamatsu, Shizuoka, Japan on March 28, 1997. http://www.unu.edu/unupress/asian-values.html\#DEBATE (accessed October 6, 2019).

Korea Times. 2007. "Full Text of Joint Declaration." http://www.koreatimes.co.kr/www/ news/nation/2007/10/116_11347.html (accessed October 6, 2019).

Lam, Peng Er. 2006. "Japan's Human Security Role in Southeast Asia." Contemporary Southeast Asia 28 (1): 141-59.

Lederach, John Paul. 1998. Building Peace: Sustainable Reconciliation in Divided Societies. Washington, DC: United States Institute of Peace.

Lederach, John Paul. 1999. The Journey Toward Reconciliation. Scottdale: Herald Press.

Lee, Seungjoo. 2014. "Multilayered World Order and South Korea's Middle Power Diplomacy: The Case of Development Cooperation Policy." EAI MPDI Working Paper, October. https://www.eai.or.kr/data/bbs/eng_report/2014102816225492.pdf (accessed October 6, 2019).

Martin, Curtis H. 2007. “'Good Cop/Bad Cop’ As a Model for Nonproliferation Diplomacy Toward North Korea and Iran." The Nonproliferation Review 14 (1): 61-68.

Moon, Chung-In. 2012. Sunshine Policy: In Defense of Engagement as a Path to Peace in Korea. Seoul: Yonsei University Press.

Moon, K. Y. 2011. “The Role of Humanitarian NGOs: Impact on South Korean Food Aid Policy towards North Korea from 1995-2007.” Ph.D. diss, Cranfield University.

Morada, Noel M. 2008. "ASEAN at 40: Prospects for Community Building in Southeast Asia." Asia-Pacific Review 15 (1): 36-55.

MOU (Ministry of Unification). 2005. Unification White Paper. Seoul: Ministry of Unification.

Murayama, Tomiichi. 1995. "Statement at World Summit for Social Development," Copenhagen, 11 March. http://www.un.org/documents/ga/conf166/gov/ 950311074922.htm (accessed October 6, 2019).

Nolan, Marcus. 2008. “The (Non) Impact of UN Sanctions on North Korea." Peterson Institute for International Economics, Working Paper Series, December. https:// www.piie.com/publications/working-papers/non-impact-un-sanctions-north-korea (accessed October 6, 2019).

Obuchi, Keizo. 1998a. "Opening Remarks by Prime Minister Obuchi at An Intellectual Dialogue on Building Asia’s Tomorrow." http://www.mofa.go.jp/announce/pm/ obuchi/index.html (accessed October 6, 2019).

Obuchi, Keizo. 1998b. "Policy Speech, Toward the Creation of A Bright Future for Asia." December 16. http://www.mofa.go.jp/region/asia-paci/asean/pmv9812/policyspeech. html (accessed October 6, 2019).

ODA Korea. 2012a. "Legal Framework." http://www.odakorea.go.kr/eng.policy.Legal.do (accessed October 29, 2019).

ODA Korea. 2012b. "Strategic Plan." http://www.odakorea.go.kr/eng.policy.StrategicPlan. do (accessed October 28, 2019).

Oga, Toru. 2014. "Is ASEAN People-Oriented or People-Centered?: The Evolution of Regionalism between Governments and Civil Society, and the Effect of Differing 
Concepts on the Drafting of the ASEAN Charter." In Global Challenges in Asia: New Development Models and Regional Community Building, eds. Hyun-Chin Lim, Wolf Schafer, and Suk-Man Hwang. Seoul: Seoul National University Press, 147-76.

OHCHR (Office of the High Commissioner for Human Rights). 2017. "US Student Case is Reminder of Prison Conditions in North Korea-UN Rights Expert." https://www. ohchr.org/EN/NewsEvents/Pages/DisplayNews.aspx? NewsID=21761\&LangID=E (accessed October 6, 2019).

Oishi, Mikio, and Fumitaka Furuoka. 2003. "Can Japan Aid be an Effective Tool of Influence?: Case Studies of Cambodia and Burma." Asian Survey 43 (6): 890-907.

Osborne, Samuel. 2017. “China Backs Burma's Efforts to 'Safeguard Stability' as Pressure Mounts over Rohingya Muslim Crisis.” The Independent, September 12. https://www. independent.co.uk/news/world/asia/china-burma-rogingya-muslim-crisis-safeguardstability-support-east-asia-massacre-army-a7941916.html (accessed October 6, 2019).

Özerdem, Alpaslan. 2010. “The 'Responsibility to Protect' in Natural Disasters: Another Excuse for Interventionism? Nargis Cyclone, Myanmar.” Conflict, Security \& Development 10 (5): 693-713.

Park, In-kook. 2009. "Statement by H.E. Mr. Park In-kook, Permanent Representative of the Republic of Korea to the United Nations, Plenary Meeting of the General Assembly on Responsibility to Protect." July 23. http://www.responsibilitytoprotect. org/Korea_ENG.pdf (accessed October 6, 2019).

Pawelz, J. 2015. "Security, Violence, and Outlawed Martial Arts Groups in Timor-Leste." Asian Journal of Peacebuilding 3 (1): 121-36.

Pitsuwan, Surin. 2008. "Keynote Address by ASEAN Secretary-General Dr. Surin Pitsuwan: Launch of the RSIS Centre for Non-Traditional Security (NTS) Studies." May 6, Traders Hotel, Singapore.

Platypus Magazine. 2008. "Operation Comity-Forces Combine Following Assassination Attempts." Edition 99, July 22-23.

Price, D. 2016. Incident Management Advisor, USDA Forest Service International Programs, Coordinator of the Emergency Operations Center, Ministry of Social Welfare, Relief and Resettlement. Interviewed by author in Naypyidaw, January 20.

Reddy, R. 2011. Senior Gender Advisor to UNMIT. Interviewed by author in Dili, August 4. Richmond, Oliver P. 2006. “The Problem of Peace: Understanding the 'Liberal Peace." Conflict, Security \& Development 6 (3): 291-314.

Rothschild, Emma. 1995. “What Is Security?” Daedalus 124 (3): 53-98.

Rudd, Kevin. 2011. "The Rise of the Asia Pacific and the Role of Creative Middle Power Diplomacy." Speech, Oslo University, Norway, May 19.

Selby, Jan. 2013. "The Myth of Liberal Peace-Building." Conflict, Security \& Development 13 (1): 57-86.

Selth, Andrew. 2008. "Even Paranoids Have Enemies: Cyclone Nargis and Myanmar's Fears of Invasion." Contemporary Southeast Asia 30 (3): 379-402.

Smith, Martin. 1999. Burma: Insurgency and the Politics of Ethnicity. New York: Zed Books. Smith, Martin. 2007. State of Strife: The Dynamics of Ethnic Conflict in Burma, Policy Studies, No. 36. Washington, DC: East-West Center.

Soeya, Yoshihide. 2005. "Japanese Security Policy in Transition: The Rise of International and Human Security." Asia-Pacific Review 12 (1): 103-16.

Stover, Eric, and Patrick Vinck. 2008. "Cyclone Nargis and the Politics of Relief and 
Reconstruction Aid in Burma (Myanmar)." The Journal of the American Medical Association 300 (6): 729-31.

Thompson, Mark R. 2004. "Pacific Asia after 'Asian Values': Authoritarianism, Democracy, and 'Good Governance.” Third World Quarterly 25 (6): 1079-95.

Timor-Leste, Government of. 2011. Strategic Development Plan 2011-2030. Dili: Government of the Republic of Timor-Leste.

UNPKO (United Nations Department of Peace Keeping Operations and Department of Field Support). 2008. United Nations Peacekeeping Operations Principles and Guidelines. New York: United Nations.

UNEP (United Nations Environment Programme). 2009. Learning from Cyclone Nargis: Investing in the Environment for Livelihoods and Disaster Risk Reduction. https:// wedocs.unep.org/bitstream/handle/20.500.11822/14116/myanmar_cyclonenargis_ case_study.pdf? sequence $=1$ \&isAllowed $=y$ (accessed October 6, 2019).

UN (United Nations) Foundation. 2002. "United Nations Peacekeeping Success Story: East Timor Celebrates First Independence Day." May 31. http://www.unfoundation.org/ news-and-media/press-releases/2005-1997/2002/un-peacekeeping-sucess-story-easttimor.html (accessed October 6, 2019).

UNHRC (United Nations Human Rights Council). 2019. "Report of the Special Rapporteur on the Situation of Human Rights in the Democratic People's Republic of Korea, Note by the Secretariat." A/HRC/40/66, March 9. https://reliefweb.int/report/ democratic-peoples-republic-korea/report-special-rapporteur-situation-humanrights-3 (accessed October 7, 2019).

Ur-Rehman, Hamid. 2010. “The Korean Peninsula: Peaceful Engagement for Humanitarian Concerns." NTS-Asia Research Paper No. 3, RSIS Centre for Non-Traditional Security (NTS) Studies for NTS-Asia. https://www.rsis.edu.sg/wp-content/uploads/rsis-pubs/ NTS/HTML-Newsletter/Report/pdf/NTS-Asia_RP_Hamid-ur-Rehman.pdf (accessed October 6, 2019).

USAID (United States Agency for International Development). 2018. "Democracy, Human Rights, and Rule of Law." https://www.usaid.gov/burma/our-work/democracyhuman-rights-and-rule-law (accessed October 6, 2019).

Wilkins, Thomas S. 2014. "Australia: A Traditional Middle Power Faces the Asian Century." In Middle Powers and the Rise of China, eds. Bruce Gilley, and Andrew O'Neil. Washington, DC: Georgetown University Press, 149-70.

WFP (World Food Program). 2019. “DPR Korea Rapid Food Security Assessment.” https:// docs.wfp.org/api/documents/WFP0000104948/download/?_ga=2.172887331. 1804488308.1557976745-10725234.1557976745 (accessed October 6, 2019).

Brendan Howe is Associate Dean and Full Professor at the Graduate School of International Studies, Ewha Womans University, Korea. He is currently President of the Asian Political and International Studies Association, and Co-President of the Korean International Studies Association. He researches on human security, peacebuilding, middle power diplomacy, and democratic governance in East Asia, and has published a dozen books and over 80 articles and book chapters on related topics. Recent major publications include Regional Cooperation for Peace and Development (Routledge, 2018), National Security, Statecentricity, and Governance in East Asia (Springer, 2017), Peacekeeping and the Asia-Pacific (with Boris Kondoch, Brill, 2016), Democratic Governance in Northeast Asia (Palgrave, 
2015), Post-Conflict Development in East Asia (Ashgate, 2014), and The Protection and Promotion of Human Security in East Asia (Palgrave, 2013). Email: bmg.howe@gmail.com.

Submitted: July 24, 2019; Revised: September 9, 2019; Accepted: September 11, 2019 